\title{
Genetic polymorphisms in diabetics and non-diabetics
}

\author{
D. R. R. WILliamS AND R. A. CARTWRIGHT \\ From the MRC Dunn Clinical Nutrition Centre, Addenbrookes Hospital, Trumpington Street, \\ Cambridge CB2 1QE; and the Yorkshire Regional Cancer Organisation, Cookridge Hospital, \\ Leeds LS16 6QB
}

SUMMARY Phenotype distributions of some genetic polymorphisms are reported in a sample of 721 diabetics and 515 non-diabetic, non-blood donor controls. Reference is also made, in the case of the $\mathrm{ABO}$ and Rhesus systems, to previously published results for blood donors resident in the Durham area. Non-insulin-taking diabetics show an increased frequency of blood group $\mathrm{A}_{1}$ (and $A_{1}+A_{2}$ ) when compared with controls. This difference is particularly marked in male diabetics. When diabetics are compared with age matched controls, the difference is confined to the older cases. It is proposed that this effect is predominantly the result of a deficiency of group $A_{1}$ in controls rather than the result of increased susceptibility to the disease among $A_{1}$ people. No association with any of the Rhesus phenotypes is shown. In non-diabetics, the results suggest an enhanced survival value for the rr genotype.

No significant associations are seen when the MNSs, Kell, Lewis, Duffy, haptoglobin, red cell acid phosphatase, phosphoglucomutase, adenylate kinase, and adenosine deaminase distributions in these groups of subjects are compared.

The ABO blood groups of diabetics have been extensively studied since McConnell's suggestion, in 1955 , of an increased frequency of blood group $A$ in these patients. Despite considerable effort, however, this approach has contributed little to knowledge of the hereditary factors involved in the predisposition to diabetes, and there has been some measure of disagreement among the authors concerned. Other red cell polymorphisms and serum protein systems have been less well studied in diabetics and few clear conclusions have been drawn.

The present study was undertaken to investigate the distribution of some of these polymorphisms in diabetics and in non-diabetic controls. The results for the esterase-D polymorphism in these subjects have been published elsewhere (Williams and Cartwright, 1978), as have those for the histocompatibility antigens (Williams, 1977).

Two features distinguish this particular study. Firstly, the sample of diabetics consists of a large proportion of the out-patients attending one particular hospital, and the phenotype frequencies in these patients are analysed in terms of current treatment, current age, and sex. Secondly, the controls are drawn from the same geographical area as the diabetics, are age matched with them for Received for publication 29 December 1978 analysis, and are not a sample of blood donors, though previously published data from donors are included for comparison.

\section{Materials and methods}

\section{DiABETIC SUBJECTS}

Patients were chosen from those attending outpatient clinics at Dryburn Hospital, Durham. Venous blood samples were taken from 721 of the diabetics attending between November 1974 and June 1976. This represents about $75 \%$ of the total attendance during this time. Sampling was not random since patients attending more frequently had a greater chance of selection. The series collected was slightly younger in mean age and consisted of a higher proportion of insulin-taking patients and a lower proportion of diet-treated patients than the complete out-patient population, though these differences were not significant (Williams, 1977).

\section{CONTROL SUBJECTS}

These were selected from three sources: (a) age and sex matched neighbours of some of the diabetics (72 subjects); (b) patients attending the orthopaedic department of Dryburn hospital for treatment of traumatic conditions, mainly fractures and head 
injuries (397 subjects); and (c) students at the University of Durham whose permanent address was within County Durham (46 subjects). These subjects were accepted as controls only after proving the absence of glycosuria. Urine samples were taken 1 to 2 hours after the largest meal of the day in the neighbour group, during routine ward testing in the orthopaedic group, and at entry to the University in the student group.

The ABO and Rhesus (D) results were compared with previously published frequencies for blood donors resident in the area by summation of the results given by Kopeć (1970) for the following areas: Stanley, Birtley, Washington, Chester-le-Street, Houghton-le-Spring, Seaham, Easington, Horden, Durham, Spennymoor, Ferryhill, and Crook.

\section{BLOOD GROUPING AND ELECTROPHORESIS}

Venous blood was taken into heparinised tubes and, after centrifugation and removal of serum, the erythrocytes were washed three times in saline and resuspended to give a $4 \%$ solution.

All samples were tested with anti-A, anti-B, anti$A B$, anti-C, anti-c, anti-D, and anti-E antisera. Those positive with anti-E were also tested with anti-e. Varying numbers of the samples (depending on the availability of antisera) were tested with anti-M, anti-N, anti-S, anti-s, anti-Le (a), anti-Fy ${ }^{\mathbf{a}}$, and anti-Fyb. First-line antisera were gifts from various sources (see acknowledgements). Confirmation of uncommon Rhesus phenotypes was carried out with second-line antisera derived from commercial sources (Ortho and Biotest). Most samples were grouped in parallel with commercial control cells, all grouping being completed within 24 hours of the blood being taken.

Haptoglobin, red cell acid phosphatase, phospho-. glucomutase, adenylate kinase, and adenosine deaminase characterisations were performed by starch gel electrophoresis using a number of methods summarised elsewhere (Williams, 1977).

ANALYSIS

Statistical analysis was performed on an IBM 370/ 167 computer complex using facilities available in the Statistical Package for Social Sciences (SPSS).

\section{Results}

\section{PLACE OF BIRTH}

A total of $92 \%$ of the controls and $60 \%$ of the diabetics were asked for their county of birth. There were no significant differences between the two groups (Table 1). Parental place of birth was also asked of these subjects and there were, similarly, no differences between the diabetics and controls
Table 1 County of birth of diabetics and non-blood donor controls (counties previous to 1974 reorganisation)

\begin{tabular}{|c|c|c|}
\hline Birth place & Diabetics & Controls \\
\hline $\begin{array}{l}\text { County Durham } \\
\text { Neighbouring counties (Northum- } \\
\text { berland, Westmorland, Cumber- } \\
\text { land and Yorkshire) }\end{array}$ & $326(75 \cdot 3 \%)$ & $346(72 \cdot 7 \%)$ \\
\hline Elsewhere in UK & $34(7.8 \%)$ & $40(8.4 \%)$ \\
\hline Unsure of birth place & $42(9.7 \%)$ & $56(11.8 \%)$ \\
\hline Total asked & 433 & 476 \\
\hline
\end{tabular}

with regard to the proportion with two, one, or ne parents born in County Durham.

There were no significant differences in the phenotype frequencies of County Durham-borier subjects and immigrants, so that the following analysis takes no account of place of birth.

\section{DISEASE STATUS}

The ABO results for diabetics and non-diabetic without regard to age or sex are shown in Table 20 Diabetics are subdivided into insulin-taking and non-insulin-taking, since there were no significant differences in the $\mathrm{ABO}$ phenotype frequenciess between the 252 oral hypoglycaemic-treated and the 239 diet-treated patients.

The frequencies of the subtypes of group A and $\mathrm{AB}$ are not available for blood donors. For the purpose of comparison, the numbers of diabetics an controls without subdivision of groups $A$ and $A B$ are given. The differences between the donors and the non-donor controls are small and not statisticall\$ significant. There are no significant differences? between the phenotype frequencies of the insulin? taking diabetics and of either of the two controt

Table $2 A B O$ phenotype frequencies in diabetics and controls

\begin{tabular}{|c|c|c|c|c|c|}
\hline Phenotype & $\begin{array}{l}\text { Insulin- } \\
\text { taking } \\
\text { diabetics }\end{array}$ & $\begin{array}{l}\text { Non- } \\
\text { insulin- } \\
\text { taking } \\
\text { diabetics }\end{array}$ & $\begin{array}{l}\text { All } \\
\text { diabetics }\end{array}$ & $\begin{array}{l}\text { Non- } \\
\text { blood } \\
\text { donor } \\
\text { controls }\end{array}$ & $\begin{array}{l}\text { Blood } \\
\text { donor } \\
\text { controls } \\
\text { (Kopeć, } \\
\text { 1970) }\end{array}$ \\
\hline$A_{1}$ & $\begin{array}{l}76 \\
(33.0 \%)\end{array}$ & $\begin{array}{l}186 \\
(37.9 \%)\end{array}$ & $\begin{array}{l}262 \\
(36 \cdot 3 \%)\end{array}$ & $\begin{array}{l}161 \\
(31 \cdot 3 \%)\end{array}$ & \\
\hline $\mathbf{A}_{2}$ & $\begin{array}{l}13 \\
(5.7 \%)\end{array}$ & $\begin{array}{l}34 \\
(6.9 \%)\end{array}$ & $\begin{array}{l}47 \\
(6.5 \%)\end{array}$ & $\begin{array}{l}36 \\
(7.0 \%)\end{array}$ & \\
\hline $\mathbf{A}_{1}+\mathbf{A}_{2}$ & $\begin{array}{l}89 \\
(38.7 \%)\end{array}$ & 220 & 309 & $(38.3 \%)$ & $\begin{array}{l}1849 \\
(38.3 \%)\end{array}$ \\
\hline o & $(46.1 \%)$ & 215 & $\begin{array}{l}321 \\
(44 \cdot 5 \%)\end{array}$ & $(49 \cdot 5 \%)$ & $\begin{array}{l}2367 \\
(49.0 \%\end{array}$ \\
\hline B & 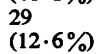 & $\begin{array}{l}44 \\
(9.0 \%)\end{array}$ & $\begin{array}{l}73 \\
(10.1 \%)\end{array}$ & $\begin{array}{l}47 \\
(9 \cdot 1 \%)\end{array}$ & $\begin{array}{l}443 \\
(9.2 \%)\end{array}$ \\
\hline$A_{1} B$ & $\begin{array}{l}4 \\
(1.7 \%)\end{array}$ & $\begin{array}{l}8 \\
(1.6 \%)\end{array}$ & $\begin{array}{l}12 \\
(1.7 \%)\end{array}$ & $(2.3 \%)$ & \\
\hline $\mathbf{A}_{2} \mathbf{B}$ & $\begin{array}{l}2 \\
(0.9 \%)\end{array}$ & $\begin{array}{l}4 \\
(0.8 \%)\end{array}$ & $\begin{array}{l}6 \\
(0.8 \%)\end{array}$ & $\begin{array}{l}4 \\
(0.8 \%)\end{array}$ & \\
\hline$A_{1} B+A_{2} B$ & 6 & 12 & 18 & 16 & 174 \\
\hline Totals & 230 & $\begin{array}{l}12 \cdot 4 \\
491\end{array}$ & 721 & $\begin{array}{l}(3.1 \%) \\
515\end{array}$ & $\begin{array}{l}(3.6 \%) \\
4833\end{array}$ \\
\hline
\end{tabular}


Table 3 Relative incidence ( $A B O$ system) in diabetics and controls

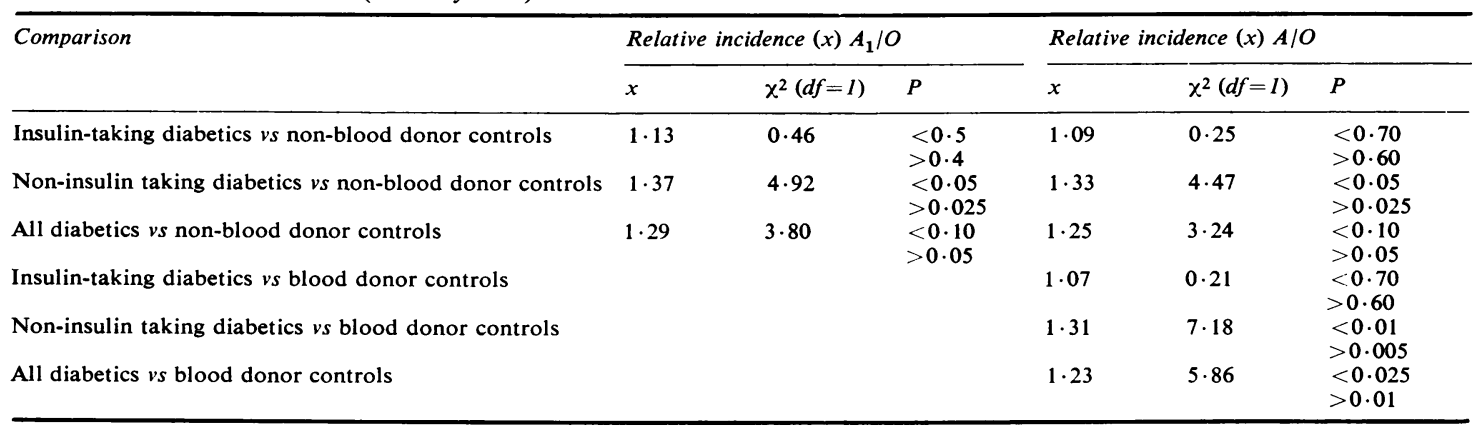

groups, but the non-insulin-taking diabetics differ from both control groups and from the insulintaking diabetics in having a higher frequency of group $\mathbf{A}_{1}$ (and, therefore, of $\mathbf{A}_{1}+\mathbf{A}_{2}$ ), and a lower frequency of group $\mathrm{O}$. These differences are expressed in terms of $A_{1} / O$ and $A / O$ ratios in Table 3. $\chi^{2}$ values are calculated by the method of Woolf (1955). The relative incidences differ significantly $(P<0.05)$ from unity when non-insulin-taking diabetics are compared with either control group. The diaberic group as a whole differs significantly only from the larger donor control group.

Rhesus phenotype frequencies in diabetics and controls are given in Table 4 (D only) and Table 5

Table 4 Rhesus $(D)$ results for diabetics and controls

\begin{tabular}{|c|c|c|c|c|c|}
\hline Phenotype & $\begin{array}{l}\text { Insulin- } \\
\text { taking } \\
\text { diabetics }\end{array}$ & $\begin{array}{l}\text { Non- } \\
\text { insulin- } \\
\text { taking } \\
\text { diabetics }\end{array}$ & $\begin{array}{l}\text { All } \\
\text { diabetics }\end{array}$ & $\begin{array}{l}\text { Non- } \\
\text { blood } \\
\text { donor } \\
\text { controls }\end{array}$ & $\begin{array}{l}\text { Blood } \\
\text { donor } \\
\text { controls }\end{array}$ \\
\hline $\begin{array}{l}\text { Rhesus (D) } \\
\text { negative } \\
\text { Rhesus (D) } \\
\text { positive } \\
\text { Totals }\end{array}$ & $\begin{array}{l}39 \\
(17.0 \%) \\
190 \\
(83.0 \%) \\
229\end{array}$ & $\begin{array}{l}87 \\
(17 \cdot 7 \%) \\
405 \\
(82 \cdot 3 \%) \\
492\end{array}$ & $\begin{array}{l}126 \\
(17 \cdot 5 \%) \\
595 \\
(82 \cdot 5 \%) \\
721\end{array}$ & $\begin{array}{l}89 \\
(17 \cdot 3 \%) \\
426 \\
(82 \cdot 7 \%) \\
515\end{array}$ & $\begin{array}{l}927 \\
(19 \cdot 2 \%) \\
3906 \\
(80 \cdot 8 \%) \\
4833\end{array}$ \\
\hline
\end{tabular}

(results with all antisera used). Results for the donors are only available for the $\mathrm{D}$ locus.

The frequency of Rhesus negative subjects in the blood donor group (Table 4) is higher than in the non-blood donor controls and the diabetic groups, but none of these differences is statistically significant in these samples.

The deficiency of the CcDee phenotype among insulin-taking diabetics (Table 5) is not significant $\left(\chi^{2}\right.$ $=9.49$ for 5 degrees of freedom, the two smallest catagories having been amalgamated, $0 \cdot 10>P>0.05)$.

The remaining polymorphisms showed no significant differences between diabetics and non-diabetics.

\section{AGE AND SEX}

There are no analyses of the ABO and Rhesus systems by age or sex for blood donors in the Durham area. When the ABO phenotype frequencies of diabetics and age matched controls (non-blood donors) are compared (Table 6), the largest differences are seen to lie in the oldest group. The $A_{1} / O$ relative incidence in this group is $1.69\left(\chi^{2}\right.$ with one degree of freedom $=6 \cdot 16, \mathrm{P}<0.025)$. It does not differ significantly from unity in the other two age groups. It may be seen that, in the diabetics, the frequency of group $A_{1}$ increases with increasing age

Table 5 Rhesus phenotypes in diabetics and controls

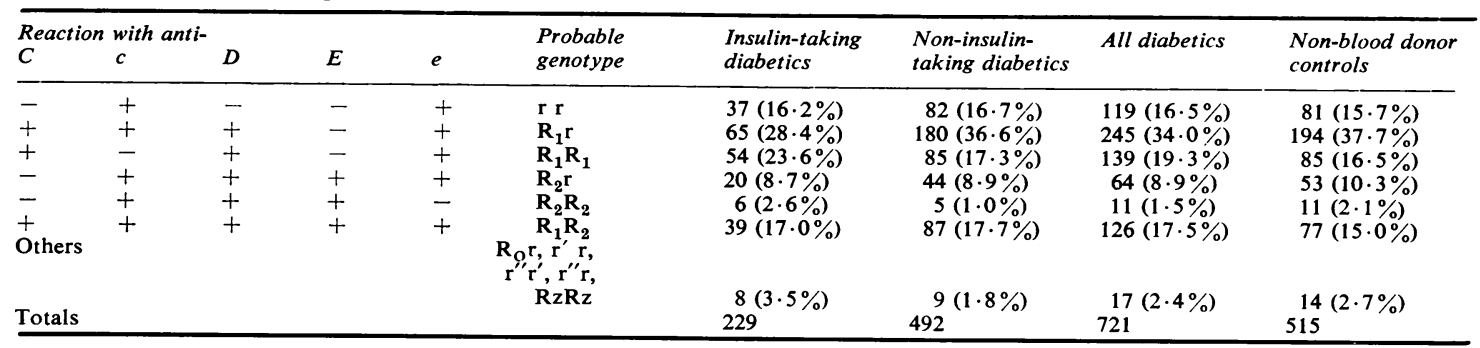


Table 6 ABO phenotype frequencies in diabetics and controls matched for age

\begin{tabular}{|c|c|c|c|c|c|c|}
\hline \multirow[t]{2}{*}{ Phenotype } & \multicolumn{2}{|l|}{ Aged under 40} & \multicolumn{2}{|l|}{ Aged 40-59 } & \multicolumn{2}{|l|}{ Aged 60 and over } \\
\hline & $\begin{array}{l}\text { Diabetics } \\
23.97( \pm 0.9)^{*}\end{array}$ & $\begin{array}{l}\text { Non-diabetics } \\
24 \cdot 52( \pm 0 \cdot 5)^{*}\end{array}$ & $\begin{array}{l}\text { Diabetics } \\
51 \cdot 70( \pm 0.4)^{*}\end{array}$ & $\begin{array}{l}\text { Non-diabetics } \\
50 \cdot 80( \pm 0.5)^{*}\end{array}$ & $\begin{array}{l}\text { Diabetics } \\
70 \cdot 32( \pm 0 \cdot 32)^{*}\end{array}$ & $\begin{array}{l}\text { Non-diabetics } \\
71.91( \pm 0.6)^{*}\end{array}$ \\
\hline $\begin{array}{l}\mathbf{A}_{1} \\
\mathbf{A}_{2} \\
\mathbf{A}_{1}+\mathbf{A}_{2} \\
\mathbf{O} \\
\mathbf{B} \\
\mathbf{A B}\end{array}$ & $\begin{array}{r}37(32 \cdot 2 \%) \\
6(5 \cdot 2 \%) \\
43(37.4 \%) \\
55(47 \cdot 8 \%) \\
14(12 \cdot 2 \%) \\
3(2.6 \%)\end{array}$ & $\begin{array}{r}71(32.4 \%) \\
17(7.8 \%) \\
88(40.2 \%) \\
106(48.4 \%) \\
17(7.8 \%) \\
8(3.7 \%)\end{array}$ & $\begin{array}{r}71(34.1 \%) \\
15(7.2 \%) \\
86(41.3 \%) \\
99(47.6 \%) \\
20(9.6 \%) \\
3(1.4 \%)\end{array}$ & $\begin{array}{r}42(32.8 \%) \\
7(5.5 \%) \\
49(38 \cdot 3 \%) \\
61(47.7 \%) \\
14(10 \cdot 9 \%) \\
4(3.1 \%)\end{array}$ & $\begin{array}{r}154(38.7 \%) \\
26(6.5 \%) \\
180(45.2 \%) \\
167(42.0 \%) \\
39(9.8 \%) \\
12(3.0 \%)\end{array}$ & $\begin{array}{r}48(28.6 \%) \\
12(7.1 \%) \\
60(35.7 \%) \\
88(52.4 \%) \\
16(9.5 \%) \\
4(2.4 \%)\end{array}$ \\
\hline Totals & 115 & 219 & 208 & 128 & 398 & 168 \\
\hline
\end{tabular}

at the expense of group $O$. In controls the reverse is the case, with a decline in the frequency of $A_{1}$ and an increase in that of group $O$. None of these trends is statistically significant in these samples.

When the ABO phenotype frequencies of diabetics are compared with controls matched for sex (Table 7 ), the differences are seen predominantly in the males where the $A_{1} / O$ relative incidence is 1.4 $\left(\chi^{2}=3 \cdot 18, \mathrm{df}=1,0 \cdot 1>P>0.05\right)$. The relative incidence in females is $1 \cdot 19\left(\chi^{2}=0 \cdot 22, \mathrm{df}=1\right)$. The differences in phenotype frequencies between male and female diabetics and male and female controls are not significant.

The relationship of Rhesus (D) frequencies to age in the control group is more striking (Table 8). There is a significant upward trend of Rhesus negative

Table $7 A B O$ phenotype frequencies in diabetics and controls subdivided by sex

\begin{tabular}{|c|c|c|c|c|}
\hline \multirow[t]{2}{*}{ Phenotype } & \multicolumn{2}{|l|}{ Males } & \multicolumn{2}{|l|}{ Females } \\
\hline & Diabetics & $\begin{array}{l}\text { Non- } \\
\text { diabetics }\end{array}$ & Diabetics & $\begin{array}{l}\text { Non- } \\
\text { diabetics }\end{array}$ \\
\hline $\begin{array}{l}\mathbf{A}_{1} \\
\mathbf{O} \\
\mathbf{A}_{2}, \mathbf{A}_{1} \mathbf{B}_{1} \\
\mathbf{A}_{2} \mathbf{B} \text { and } \mathbf{B}\end{array}$ & $\begin{array}{r}117(37.3 \%) \\
141(44.9 \%) \\
56(17.8 \%)\end{array}$ & $\begin{array}{r}80(29.8 \%) \\
135(50.4 \%) \\
53(19.8 \%)\end{array}$ & $\begin{array}{l}145(35.6 \%) \\
180(44.2 \%) \\
82(20.2 \%)\end{array}$ & $\begin{array}{r}81(32.8 \%) \\
120(48.6 \%) \\
46(18.6 \%)\end{array}$ \\
\hline Totals & 314 & 268 & 407 & 247 \\
\hline
\end{tabular}

Table 8 Rhesus $(D)$ phenotype frequencies of controls subdivided by age

\begin{tabular}{clllll}
\hline $\begin{array}{c}\text { Subdivided by age } \\
\text { Phenotype }\end{array}$ & $\begin{array}{l}\text { Age } \\
\text { Under 20 }\end{array}$ & $20-39$ & $40-59$ & 60 and over \\
\hline $\begin{array}{c}\text { Rhesus (D) } \\
\text { negative }\end{array}$ & $10(13.0 \%)$ & $19(13.4 \%)$ & $20(15.6 \%)$ & $39(23 \cdot 2 \%)$ \\
$\begin{array}{c}\text { Rhesus (D) } \\
\text { postive } \\
\text { Totals }\end{array}$ & $67(87.0 \%)$ & $123(86.6 \%)$ & $108(84.4 \%)$ & $129(76.8 \%)$ \\
\hline & 77 & 142 & 128 & 168
\end{tabular}

frequency with increasing age of the subgroup $(P=0.0096$, test for significance of trends i proportions, Cox, 1970). The trend is present in bot sexes, but does not reach statistical significance im either sex taken alone. No trend is found in insulin taking or in non-insulin-taking diabetics. Whes age matched controls are compared with insulin taking and non-insulin-taking diabetics, there are n $\overrightarrow{\vec{\Phi}}$ significant differences in Rhesus phenotype fre quencies. When the full Rhesus phenotypes of the control group are analysed with respect to the age of the subjects (Table 9), the only clear trend is that of an increase in the frequency of the cde phenotype with increasing age.

The Rhesus phenotypes show no significan differences between the sexes, neither are ans differences apparent when diabetics and sex matched controls are compared.

Table 9 Rhesus phenotype results for control subjects subdivided by age

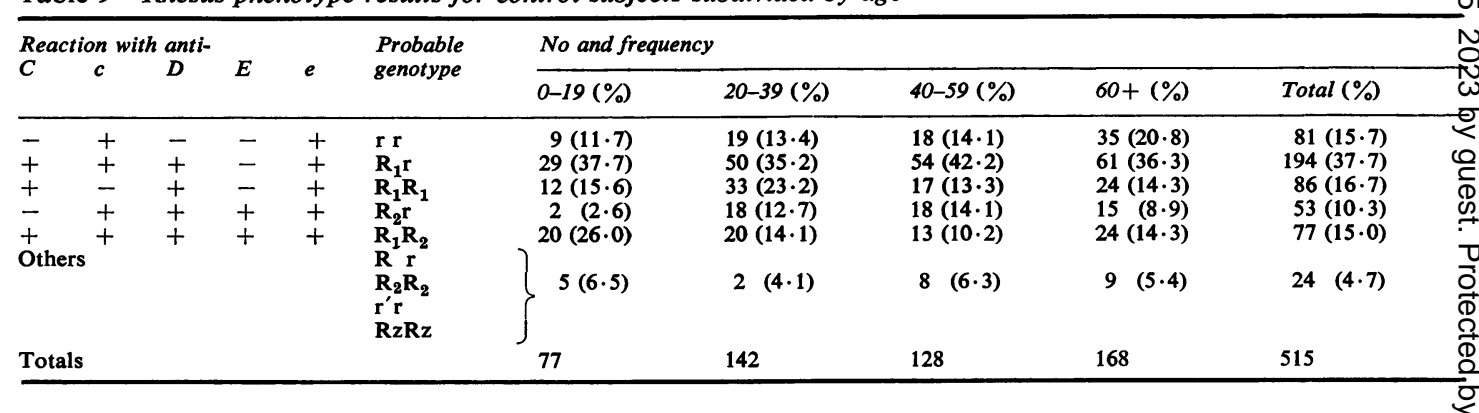




\section{Discussion}

\section{COMPARABILITY OF DISEASED AND CONTROL GROUPS}

The diabetic and control populations which form the subject of this report are entirely comparable in terms of their places of birth. The static nature of the population of the Durham area, with about threequarters of both groups born within the county, is remarkable, and is one of the advantages of this population for studies such as this. Comparability of diseased and control groups with regard to place of birth is not usually shown in studies of this nature and may be important in certain instances, expecially when use is made of blood donors as controls.

There have been criticisms of the use of such controls in comparisons of this type. Buckwalter and Knowler (1958) suggested that blood donors are more likely to be of blood group $O$ than a truly random sample of the population, though the situation in countries like the United States, with the presence of professional donors, differs from that in this country. The non-blood donor population gathered in this investigation compares well with ABO results previously published for donors from the same locality.

\section{THE ABO SYSTEM}

The finding of a higher frequency of group $\mathrm{A}_{1}$ (and, therefore, $\mathbf{A}_{1}+\mathbf{A}_{2}$ ) among diabetics than among controls (Table 3 ) supports the observations of many other workers (Craig and Wang, 1955; McConnell et al., 1956; Bibawi and Khatwa, 1961; Cornil and Pirart, 1961; Doll et al., 1961; Sauer et al., 1963; Révai and König, 1968; Ksenofontor, 1974). Other groups, however, have failed to confirm this (Simpson et al., 1962; Macafee, 1964; Berg et al., 1967) while others have found associations with other groups of this system (Speiser, 1958; Anderson and Lauritzen, 1960; Henry and Poon-King, 1961; Buckwalter, 1964). In the present study, the difference is confined to non-insulin-taking diabetics, and the pooled diabetic patients show an excess of group A only when compared with a very large control group (the blood donors). When current age is taken into account (Table 6), the excess of group $A_{1}$ is confined to the older diabetics compared with the older controls, though whether older diabetics show this difference because they are predominantly noninsulin-taking, or non-insulin-taking diabetics differ from controls because they are, by and large, older than insulin-taking diabetics cannot be satisfactorily resolved by this relatively small sample. For reasons to be discussed, the second alternative is favoured.

The results of Table 6 suggest, but do not con- clusively show, that the blood group differences in the older subjects are the result of a deficiency of group $A_{1}$ subjects among the controls, rather than an excess of $A_{1}$ subjects among the patients.

The finding of an apparent excess of group $A_{1}$ (and, therefore, of $A_{1}+A_{2}$ ) subjects, particularly among male diabetics (Table 7), has been noted before (McConnell et al., 1956; Bibawi and Khatwa, 1961 ; Révai and König, 1968). This curious finding has never been satisfactorily explained.

The usual interpretation of these phenotype differences is that group $\mathbf{A}$ (or $\mathbf{A}_{1}$ ) subjects are at a greater risk of developing diabetes, and that this is especially so in males and in persons who develop the disease in later life. There is an alternative explanation, however, which is consistent with the present results and those of some other investigations concerned with the effect of age upon ABO phenotype frequencies in the general population, and which accounts for the sex effect seen and the conflict in published reports in a more satisfactory manner than before.

Jörgensen and Schwarz (1968), in their study of healthy subjects, showed an excess of group $O$ in the elderly compared with a group of younger donors from the same locality. Similarly, Van Houte and Kesteloot (1972), in a study of a large number of male soldiers aged 16 to 60 , showed a significantly higher frequency of group $\mathbf{O}$ and a significantly lower frequency of group $A$ in the 55 to 60 age group compared with younger age groups. Both groups of workers suggested that group $O$ subjects were at a selective advantage compared with those of group $\mathbf{A}$. Jörgensen and Schwarz (1968) considered that relative susceptibility to neoplasm might be responsible. Van Houte and Kesteloot showed significantly higher serum cholesterol levels in persons of group A compared with those of group $\mathrm{O}$, but considered that differential mortality from cardiovascular disease was insufficient alone to account for the effect they found, and differential susceptibility to infections might also play a part.

The results of this study (Table 6) tend to support the observations that older groups of normal people show an increased frequency of blood group $O$ compared with the younger groups. If differential mortality with respect to ABO phenotype does exist and is absent from the diabetic group, an apparent excess of group A subjects among the diabetics would result. Diabetics are envisaged as being independent of this effect, not because they do not die from the disease or diseases responsible, but because their diabetic state is such an overwhelming risk factor that the small differences in mortality, resulting from ABO phenotypes in controls, are not seen. 
The greater $\mathrm{A} / \mathrm{O}$ relative incidence seen in male diabetics would result if differential mortality was more marked among male non-diabetics than among female non-diabetics because of a greater prevalence of, or higher mortality from, the disease(s) in question among males.

The conflict seen in previous reports on this subject may, very largely, be the result of different admixtures of cases among the diseased groups (with regard to treatment category, age at diagnosis, and current age), and different interrelationships of diseased and control groups with respect to age. In general, published reports give insufficient information, especially with regard to the age structure of control groups, to allow this to be evaluated.

Clearly, the hypothesis put forward here is tentative and unsubstantiated. Other investigations, concerned purely with blood donors, have failed to find any relationship between $\mathrm{ABO}$ phenotype and age (Roberts, 1948; Bennett and Walker, 1956; Buckwalter and Knowler, 1958). Our knowledge of the relative survival value of the ABO blood groups is very much in its infancy, though Kesteloot et al. (1977) have strongly advocated matching diseased and control groups for age when studying this polymorphism. It was for this reason that we matched our controls with the cases in respect of age.

Our suggestion has the advantage, however, that, whereas no remotely tenable hypothesis has been advanced for the increased susceptibility to diabetes of group $A_{1}$ subjects, there are at least some suggestions for mechanisms connecting $\mathrm{ABO}$ status and susceptibility to the development of atherosclerosis (see Morton, 1976, for review). In addition, the proposition that one biological mechanism is responsible for several effects is intrinsically more satisfying than the proposal that each of these several effects is the result of an independent cause, especially if the simpler solution is capable of resolving a conflict in the published data. The testing of this hypothesis, preferably on a prospective basis, in diabetics and controls would be worthwhile.

\section{THE RHESUS SYSTEM}

Seeff et al. (1975) have suggested that blood donors especially females, have a higher frequency of Rhesus negative people than the general population. The results presented here (Table 4) do indeed show a higher frequency of this phenotype in donors than in non-donor controls, though the difference is not significant with this small sample.

Analysis of the Rhesus system in this population suggests stronger indications for age matching than are found in an analysis of the ABO system. In the control population, there is a marked age trend (Table 8). This trend cannot be explained by hetero- geneity of the sub-groups with regard to sex or place of birth. In the absence of any alternative explanation, we put forward the suggestion that? Rhesus negative people are at a selective advantage compared with Rhesus positive people. There is, to our knowledge, no substantiated disease associations between the Rhesus system and a common condition capable of explaining these findings. Further work है such as the analysis by age of existing donor records, is clearly required before this suggestion can be accepted. The absence of this trend from the $\vec{\omega}$ diabetic group may indicate that this is a chance finding, though it may be the result of the fact tha $\bar{B}$ the selection is not operational in diabetics in a similar manner to the situation proposed for the $\mathrm{G}$ ABO system.

Previous studies of the Rhesus phenotype frequencies of diabetics and controls have beeno conflicting. Buckwalter and Tweed (1962) found no significant differences between their diseased group and their control group. Berg et al. (1967) found af significant excess of the $c D E\left(\mathrm{R}_{2}\right)$ haplotype amongo their diabetics while Scholz et al. (1975) found that the $C D e\left(\mathrm{R}_{1}\right)$ and $c d e(\mathrm{r})$ haplotypes were increasede in frequency among diabetics, though the differencesc were not significant. None of the series which reported results for the $D$ locus only (Craig and Wang, 1955; McConnell et al., 1956; Zeytinoglu, 1956; Anderson and Lauritzen, 1960; Simpson et al. 1962) found significant differences between diseasedo and non-diseased groups.

It is suggested that those series which showed large differences between diabetics and controls for this system are comparing populations that are con siderably different in their ages.

There is so little known of the effects of age on $\mathrm{ABO}$ and $\mathrm{Rhesus}$ phenotypes in the population tha it seems hazardous to ascribe relative risks for 3 diabetes to individual phenotypes without stringento matching for age between the diabetic and nondiabetic populations used for comparison.

We gratefully acknowledge the permission of consultant physicians at Dryburn Hospital, Durham, especially Dr R. Mowbray, for permission to study the diabetic patients in their care, and the orthopaedion consultants of the same hospital for access to controf subjects, and to the subjects themselves for their ${ }_{\sigma}^{\omega}$ co-operation.

Antisera for blood grouping were kindly donatede by the Newcastle Blood Transfusion Service, byes Dr D. Tills of the British Museum of Naturaf History, and by the Blood Group ReferenceLaboratory (Gatliffe Road).

The technical expertise of Mr M. A. Carr and Miss $\frac{?}{\overrightarrow{6}}$ Lesley Bailey is greatly appreciated. 
DRRW was in receipt of an Addison Wheeler Research Fellowship of the University of Durham during the execution of this work. Financial assistance was received from the Catherine and Lady Grace James Foundation.

\section{References}

Anderson, J., and Lauritzen, E. (1960). Blood groups and diabetes. Diabetes, 9, 20-24.

Bennett, J. H., and Walker, C. B. V. (1956). Fertility and blood groups of some East Anglian donors. Annals of Human Genetics, 20, 299-308.

Berg, K. Aarseth, S., Lundvall, J., and Reinskou, T. (1967). Blood groups and genetic serum types in diabetes mellitus. Diabetologia, 3, 30-34.

Bibawi, E., and Khatwa, H. A. (1961). The blood groups in relation to diabetes. Journal of the Egyptian Medical Association, 44, 655-659.

Buckwalter, J. A. (1964). Diabetes mellitus and the blood groups. Diabetes, 13, 164-168.

Buckwalter, J. A., and Knowler, L. A. (1958). Blood donor controls for blood group disease researches. American Journal of Human Genetics, 10, 164-173.

Buckwalter, J. A., and Tweed, G. V. (1962). The Rhesus and MN blood groups and disease. Journal of the American Medical Association, 179, 479-485.

Cornil, A., and Pirart, J. (1961). Diabète, hémochromatose et groups sanguins. Pathologie et Biologie, 9, 1911-1915.

Cox D. R. (1970). The Analysis of Binary Data. Methuen, London.

Craig, J., and Wang, I. (1955). Blood groups and diabetes mellitus. Glasgow Medical Journal, 36, 261-266.

Doll, R., Drane, H., and Newell, A. C. (1961). Secretion of blood group substances in duodenal, gastric, and stomal ulcer, gastric carcinoma and diabetes mellitus. Gut, 2, 352-359.

Henry, M. U., and Poon-King, T. (1961). Blood groups and diabetes. West Indian Medical Journal, 10, 156-160.

Jörgensen, G., and Schwarz, G. (1968). Weitere Untersuchungen zur Frage der unterschedlichen Selektionswertigheit im ABO-Blut-gruppensystem. Humangenetik, 5, 254-260.

Kesteloot, H., den Linden, L. V., Wulleman, G., and van Houte, O. (1977). ABO blood group distribution and ischaemic heart disease. Lancet, 1, 761.

Kopeć, A. C. (1970). The Distribution of the Blood Groups in the United Kingdom. Oxford University Press, London.

Ksenofontor, Y. P. (1974). Study of genetic markers in bronchial asthma and diabetes mellitus. Soviet Genetics, 8 , 648-650.
Macafee, A. L. (1964). Blood groups and diabetes mellitus. Journal of Clinical Pathology, 17, 39-41.

McConnell, R. B. (1955). Discussion on the ABO blood groups and disease. Proceedings of the Royal Society of Medicine, 48, 291.

McConnell R. B., Pyke, D. A., and Roberts J. A. F. (1956). Blood groups in diabetes mellitus. British Medical Journal, 1, 772-776.

Morton, N. E. (1976). Genetic markers in atherosclerosis. A review. Journal of Medical Genetics, 13, 81-90.

Révai, S., and König, E. (1968). Vorkommen der Blutgruppen ABO bei an Diabetes mellitus leidenden Kranken. Zeitschrift für Ärztliche Fortbildung, 62, 1087-1088.

Roberts, J. A. F. (1948). The frequencies of the ABO blood groups in S.W. England. Annals of Eugenics, 14, 109-116.

Sauer, H., Mai, K., and Otto, H. (1963). Untersuchungen zur Blutgruppenverteilung bein Diabetes mellitus. Klinische Wochenschrift, 41, 1052-1054.

Scholz, W., Knussmann, R., and Daweke, H. (1975). Distribution of blood and serum protein characteristics in patients with diabetes. Diabetologia, 11, 77-82.

Seeff, L. B., Zimmerman, H. J., Wright, E. C., Gocke, D. J., and Aach, R. D. (1975). Unsuitability of blood donors for population genetics. Lancet, 1, 530-531.

Simpson, N. E., Gunson, H. H., and Smithies, O. (1962). Frequencies of blood groups, serum haptoglobins and levels of slow alpha 2 globulin in diabetics and their relatives. Diabetes, 11, 329-333.

Speiser, P. (1958). Krankheiten und Blutgruppen. Krebsarzt, 4, 208-218.

Van Houte, C., and Kesteloot, H. (1972). An epidemiological survey of risk factors for ischaemic heart disease in 42,804 men. Acta Cardiologica. 27, 527-564.

Williams, D. R. R. (1977). Genetic and Epidemiological Aspects of Diabetes Mellitus. Ph.D. Thesis, University of Durham.

Williams, D. R. R., and Cartwright, R. A. (1978). The esterase $\mathbf{D}$ polymorphisms in patients with diabetes or carcinoma of the bladder and a matched sample of nondonor controls. Annals of Human Biology, 5, 281-284.

Woolf, B. (1955). On estimating the relationship between blood groups and disease. Annals of Human Genetics, 19, 251-253.

Zeytinoglu, I. (1956). Etude de relation des groupes sanguine (ABO) et Rhesus (standard) dans le diabète. Acta Genetica, $6,564-566$.

Requests for reprints to $\operatorname{Dr} D$. R. R. Williams, Dunn Clinical Nutrition Centre, Addenbrookes Hospital, Trumpington Street, Cambridge CB2 1QE. 